\title{
Optimisation of Microwave Pretreatment for Biogas Enhancement through Anaerobic Digestion of Microalgal Biomass
}

\author{
Rui Zhe Feng ${ }^{1}$, Asad A. Zaidi', Kun Zhang ${ }^{1}$, Yue Shi ${ }^{1 *}$ \\ ${ }^{1}$ College of Power and Energy Engineering, Harbin Engineering University, Harbin 150001, Heilongjiang Province, China \\ * Corresponding author, email: shiyue@hrbeu.edu.cn
}

Received: 02 April 2018, Accepted: 04 June 2018, Published online: 15 June 2018

\begin{abstract}
In this study, optimization of microwave (MW) pretreatment conditions for anaerobic digestion of green microalgae (Enteromorpha) is carried out by using response surface methodology (RSM). MW power, pretreatment time and liquid-solid ratio were selected as independent variables for optimization. The optimum conditions were achieved at MW power, pretreatment time and liquid-solid ratio of $656.92 \mathrm{~W}, 5.10 \mathrm{~min}$ and 33.63:1, respectively. From these optimum conditions, it was found that MW pretreatment power of about $600 \mathrm{~W}$ had better effect. An anaerobic digestion was carried out batch-wise with working volume, operating temperature and mixing rate as $250 \mathrm{ml}, 37^{\circ} \mathrm{C}$ and $150 \mathrm{rpm}$, respectively. Optimum conditions provide highest amount of COD and reducing sugar increase of 10,420 $\mathrm{mg} / \mathrm{L}$ and 0.77-0.79 $\mathrm{g} / \mathrm{L}$ respectively. The increase in COD and reducing sugar showed that the pretreatment has improved anaerobic digestion of microalgae. The peak biogas production amount of MW pretreated 20:1, 6 min group reached $244 \mathrm{~mL}$ whereas the control group only reached $188 \mathrm{~mL}$ in total.
\end{abstract}

Keywords

anaerobic digestion, biofuel, biomass, microwave (MW) pretreatment, response surface methodology

\section{Introduction}

Today's society is highly dependent on fossil fuels such as crude oil, natural gas, lignite and coal [1]. These natural reserves are region specific and may cause depletion of resources in some regions after a certain amount of time. Our industrialized society is highly dependent on the use of energy sources for the continuation of its economic and welfare growth. Biomass is a renewable energy source, which has the potential to provide high energy fuel for heating, cooling and electrical purposes in its all three forms (solid, liquid and gas) [2]. Biogas is produced due to bio-decomposition of organic material caused by bacteria in anaerobic conditions. Instant storage and usage as a substitute of natural gas is the primary advantage of biogas [3]. To encounter the growing demands of energy across the world and waste disposal, production and distribution of biogas from organic matter could serve as one possible solution.

Anaerobic digestion is a biochemical and microbiological process in which decomposition of organic matter takes place in the absence of oxygen [4]. The anaerobic digestion process consists of four main conversion phases of organic matter into biogas namely; hydrolysis, acidogenesis, acetogenesis and methanogenesis [5]. In the first phase large and complex organic matter such as carbohydrates, fats and proteins react with water to form monomers by the assistance of hydrolytic bacteria. During the second phase conversion of monomers into volatile fatty acids (VFAs) is carried out by the aid of fermentative bacteria. The third phase involves the transformation of VFA into acetic acid, carbon dioxide $\left(\mathrm{CO}_{2}\right)$ and hydrogen under the action of acetogenic bacteria. During the final phase, methanogenic bacteria convert acetic acid and hydrogen into methane $\left(\mathrm{CH}_{4}\right)$ and $\mathrm{CO}_{2}[6]$. The stages of anaerobic digestion process are shown in Fig. 1.

Hydrogen production via fermentative biomass has more advantage over the traditional hydrogen preparation methods as it does not require an abundance of chemical raw materials, in addition the production process does not require consuming a lot of energy. Biological hydrogen production is better than other traditional methods of production as it is green [7]. Aquatic algal biomass, which can be sourced from natural algal bloom or mass cultivation, is considered as a 


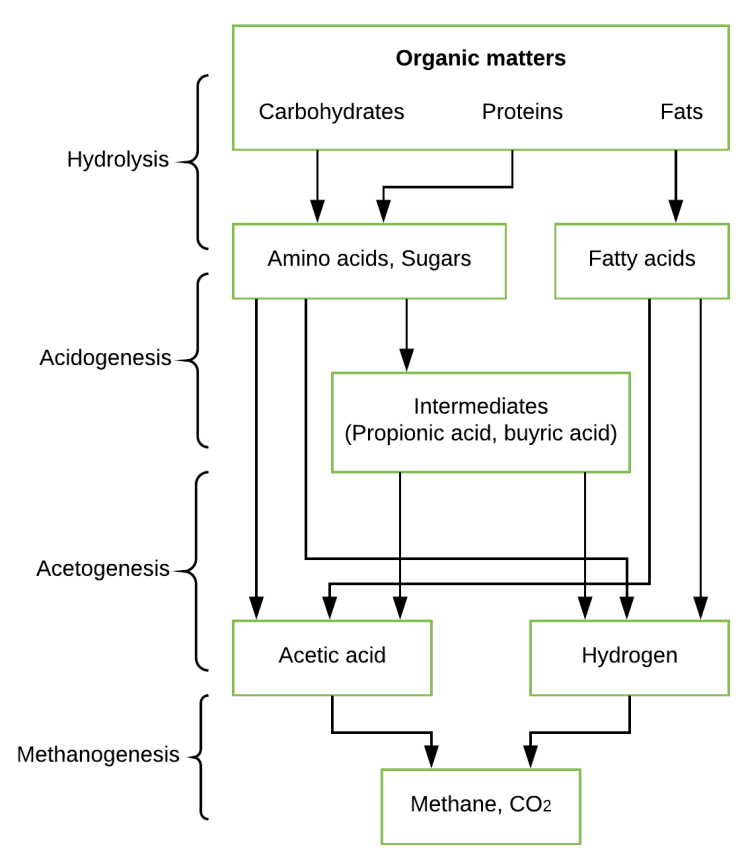

Fig. 1 Stages of anaerobic digestion process

promising substrate for hydrogen fermentation [8]. Previous studies indicated that anaerobic sludge (AS) and microalgae were co-cultured to enhance the energy conversion and nutrients removal from starch waste water [9].

Hydrolysis is considered as the rate limiting step in anaerobic digestion process. Pretreatment techniques have been used to improve hydrolysis and anaerobic digestion performance [10]. Numerous pretreatment techniques have been instigated for complex substrates, such as mechanical, thermal, chemical or biological treatments [11]. Microwave (MW) pretreatment is a thermal pretreatment method, which can obtain the desired temperature faster than conventional heating methods and the process is energy efficient too. The optimization of MW pretreatment conditions is very important in order to get an energy efficient overall improvement on fermentation conditions.

The RSM is a useful tool for improving and optimizing unknown systems or processes in combination with mathematical methods and statistical analysis [12]. In this method, an experimental design is used to effectively respond on the surface design and the statistical model of the information by establishing a fitting curve which is obtained when the experimental design is applied. The scientific map describes the relationship between the response and the variable.

The aim of the present study is to explore the effect of MW pretreatment on the anaerobic digestion of green algae (Enteromorpha). RSM is used for finding the optimum condition for the multivariate interactive factors for this method of pretreatment. To understand the effectiveness of the MW pretreatment, measurements of soluble indexes including chemical oxygen demand (COD), volatile fatty acids (VFAs), and reducing sugar were carried out.

\section{Materials and Methods}

\subsection{Raw Materials}

The anaerobic sludge used in the experiment was obtained from the Harbin Wenchang Sewage Treatment Plant, Harbin, China. It had been aeration cultured for 2 weeks, according to the ratio of 300:5:1 plus glucose, $\mathrm{NH}_{4} \mathrm{Cl}$, $\mathrm{KH}_{2} \mathrm{PO}_{4}$, with the sludge in brown color and a good settling for experiment [13]. The Enteromorpha used in the experiment was from the freshwater algae and acquired from the Institute of Hydrobiology of The Chinese Academy of Science, Wuhan, China. It had been air-dried in the Drying oven, and sealed with a breathable film in the bottle.

\subsection{Optimisation of process parameters using RSM and experimental design}

Batch experiments were conducted to analyze the effect at different MW power (400-800 W), pretreatment time (2-6 min) and liquid-solid ratio (20:1-60:1). The Enteromorpha powder was mixed with deionized water to make the desired liquid-solid ratio. All the experiments were conducted in triplicate [14].

A three-factor central composite design (CCD) was used to design the experiment for constructing models using design expert software version 8.0.6. Cumulative biogas production was chosen as the response variable, while MW power (A), pretreatment time (B) and liquid-solid ratio $(\mathrm{C})$ were used as three independent variables, as is indicated in Table 1. The experimental design and corresponding experimental results are shown in Table 2. The results presented for COD, reducing sugar and carbohydrates are after pretreatment but before fermentation experiments. It shows difference between control and pretreatment.

\subsection{Experimental Procedure}

The MW pretreatment was carried out with a microwave oven in such a way that after every minute the microalgae solution was stirred and the temperature was measured with a thermometer. The temperature during pretreatment was recorded no higher than $50{ }^{\circ} \mathrm{C}$. The anaerobic digestion of MW pretreated Enteromorpha with sludge was carried out batchwise. The experiment was divided 
Table 1 Level of the independent variables for RSM.

\begin{tabular}{lccc}
\hline $\begin{array}{l}\text { Independent } \\
\text { Variables }\end{array}$ & Parameters & $\begin{array}{c}\text { Low } \\
\text { Level }\end{array}$ & $\begin{array}{c}\text { High } \\
\text { Level }\end{array}$ \\
\hline A & MW Power (W) & 400 & 800 \\
B & Pretreatment Time (min) & 2 & 6 \\
C & Liquid-Solid Ratio & $20: 1$ & $60: 1$ \\
\hline
\end{tabular}

Table 2 Experimental design for cumulative production and corresponding experimental results

\begin{tabular}{lcccccc}
\hline Run & $\begin{array}{c}\text { Power } \\
(\mathrm{W})\end{array}$ & $\begin{array}{c}\text { Time } \\
(\mathrm{min})\end{array}$ & Ratio & $\begin{array}{c}\text { COD } \\
(\mathrm{mg} / \mathrm{L})\end{array}$ & $\begin{array}{c}\text { Reducing } \\
\text { sugar } \\
(\mathrm{mg} / \mathrm{L})\end{array}$ & $\begin{array}{c}\text { Carbonhydrate } \\
(\mathrm{mg} / \mathrm{L})\end{array}$ \\
\hline 1 & 800 & 2 & $40: 1$ & 3670 & 190 & 46 \\
2 & 600 & 2 & $60: 1$ & 2320 & 462 & 34 \\
3 & 400 & 4 & $20: 1$ & 3010 & 161 & 117 \\
4 & 600 & 6 & $20: 1$ & 5750 & 471 & 150 \\
5 & 600 & 4 & $40: 1$ & 5150 & 619 & 68 \\
6 & 800 & 4 & $60: 1$ & 4690 & 263 & 121 \\
7 & 400 & 2 & $40: 1$ & 3520 & 229 & 54 \\
8 & 400 & 6 & $40: 1$ & 5370 & 293 & 107 \\
9 & 600 & 6 & $60: 1$ & 4120 & 225 & 92 \\
10 & 400 & 4 & $60: 1$ & 1500 & 165 & 43 \\
11 & 800 & 4 & $20: 1$ & 5620 & 344 & 129 \\
12 & 600 & 2 & $20: 1$ & 6320 & 308 & 108 \\
13 & 800 & 6 & $40: 1$ & 8340 & 464 & 141 \\
\hline & & & & & & \\
\hline
\end{tabular}

into four groups, each group contained $10 \mathrm{~g} \mathrm{MW}$ pretreated Enteromorpha powder, and $30 \mathrm{ml}$ of fresh sludge (TS: $5.9 \mathrm{~g} / \mathrm{L}$ ) in a $250 \mathrm{~mL}$-scale glass bottle. The initial $\mathrm{pH}$ was adjusted at 7 by $1 \mathrm{M} \mathrm{NaOH}$ and $1 \mathrm{M} \mathrm{HCl}$. The bottles were sealed with rubber stoppers and flushed with nitrogen gas for $5 \mathrm{~min}$ [15]. The digestion environment was maintained at $37^{\circ} \mathrm{C} \mathrm{[16]} \mathrm{and} 150 \mathrm{rpm}$.

\subsection{Analytical Methods}

The measurements of soluble indexes including chemical oxygen demand (COD), $\mathrm{pH}$, volatile fatty acids (VFAs) and reducing sugar were determined according to standard methods [17]. Biomass concentration like glucose concentration was estimated by 3,5-dinitrosalicylic acid (DNS) method using spectrophotometer (DR 3900, $\mathrm{HACH}, \mathrm{USA})$ at a maximum wavelength $\left(\lambda_{\max }\right)$ of 550 $\mathrm{nm}$. The $\mathrm{pH}$ was recorded using a $\mathrm{pH}$ analyzer (PHS-3C, INESA, China). Volatile fatty acids (VFA) were analyzed using High-performance liquid chromatography (HPLC 7820A, Agilent Technologies, USA). The hydrogen content of the biogas was analyzed by gas chromatography (SP-2100A, BFRL, USA) with Thermal Conductivity Detector-Flame Ionization Detector (TCD-FID).

\section{Results and Discussion}

\subsection{Effect of MW Pretreatment on COD and} Reducing Sugar

The result of MW pretreatment on COD is shown in Fig. 2 (a). It is clearly shown that the group of liquid-solid ratio 20:1 provided the peak initial COD concentration value of $5,130 \mathrm{mg} / \mathrm{L}$ and the group $60: 1$, provided the least amount of value, i.e, $1,980 \mathrm{mg} / \mathrm{L}$. The most significant increase in COD is found to be $1,605 \mathrm{mg} / \mathrm{L}$ and $1,985 \mathrm{mg} / \mathrm{L}$ obtained by the group 40:1 ratio at the MW power of $400 \mathrm{~W}$ and $800 \mathrm{~W}$, respectively.

The change of reducing sugar concentration during the MW pretreatment is shown in Fig. 2 (b). The increase in reducing sugar with the groups of ratio 20:1 and 60:1 is not so significant. In contrast, the group with ratio 40:1 showed better performance on reducing sugar change. The highest amount of reducing sugar is found to be $0.0502 \mathrm{~g} / \mathrm{L}$. However, the group of MW power with $600 \mathrm{~W}$ indicated small increase and reached only $0.0062 \mathrm{~g} / \mathrm{L}$ of reducing
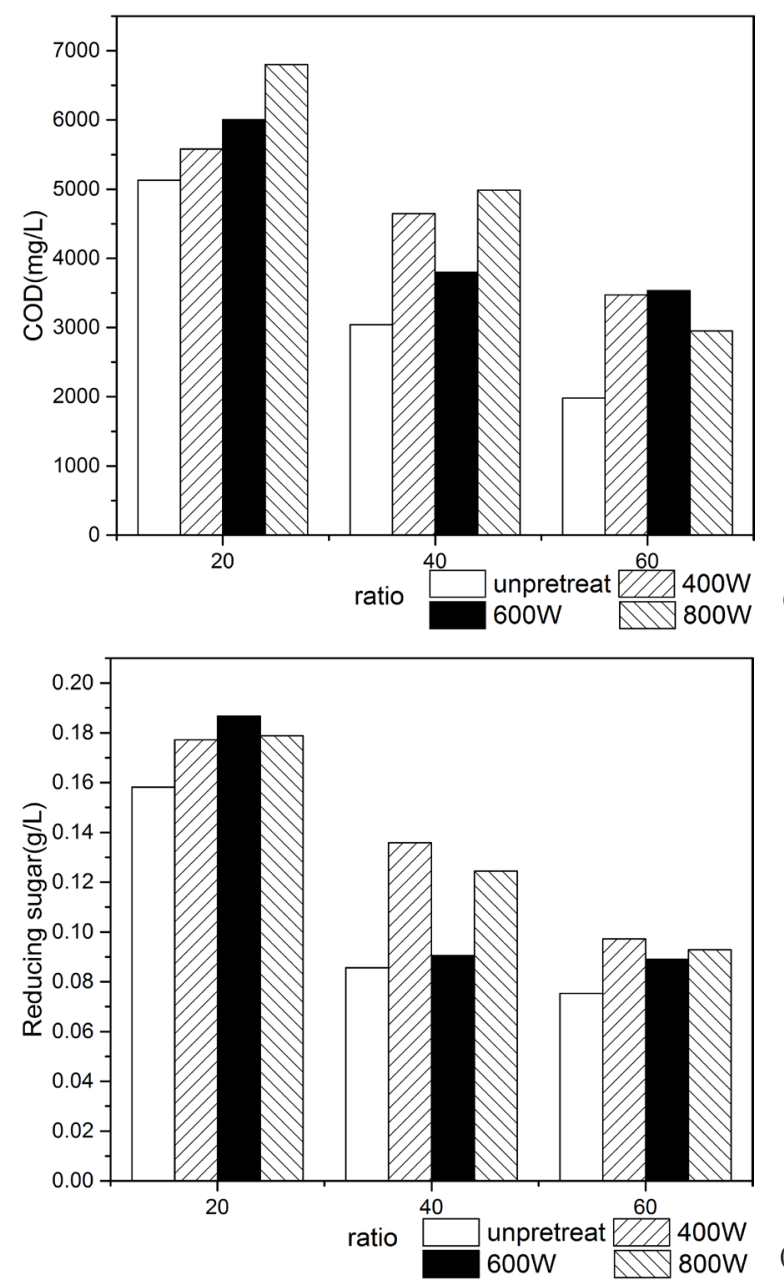

Fig. 2 (a) COD change with MW pretreatment (b) Reducing sugar change with MW pretreatment 
sugar value. The behavior at $600 \mathrm{~W}$ is found to be similar for both COD and reducing sugar.

\subsection{Optimisation of MW Pretreatment}

\section{Process Parameters}

The following regression equation (Eq. (1)) fits the experimental data of cumulative biogas production:

$$
\begin{aligned}
R \text { sugar }= & 618.69+51.63 A+33.12 B-21.28 C \\
& -52.79 A B-21.31 A C-99.95 B C \\
& -229.11 A^{2}-95.64 B^{2}-156.32 C^{2} .
\end{aligned}
$$

The ANOVA result for the quadratic model is presented in Table 3. The determination of coefficient $\mathrm{R}^{2}$ and adjusted $\mathrm{R}^{2}$ were found to be 0.9009 and 0.6036 , respectively. The ANOVA calculation shows that the P-value (Prob $>F)$ is 0.0560 , which means the relationship between the independent variables and the response values investigated in this experiment are significant and the scheme is reliable. From the impact of different factors in this experiment on the biogas production, the term $\mathrm{A}^{2}$ Prob $>\mathrm{F}$ value of ratio is 0.0303 which is less than 0.05 , meaning that $\mathrm{A}^{2}$ had significant influence in the biogas production. The term $\mathrm{C}^{2}$ also has conspicuous effect on biogas production. Further, comparing the P-value with $\mathrm{A}, \mathrm{B}$ and $\mathrm{C}$, it can be found that the influence of these 3 factors was MW power > pretreatment time $>$ liquid-solid ratio.

The response surface design results in the form of three-dimensional response curves are shown in Fig. 3.

Table 3 ANOVA of the quadratic regression model for cumulative biogas production

\begin{tabular}{lccccc}
\hline $\begin{array}{l}\text { Source } \\
\text { model }\end{array}$ & $\begin{array}{c}\text { Sum of } \\
\text { squares }\end{array}$ & $\begin{array}{c}\text { Df } \\
\text { (degree } \\
\text { of } \\
\text { freedom) }\end{array}$ & $\begin{array}{c}\text { Mean } \\
\text { square }\end{array}$ & F value & $\begin{array}{c}\text { P-value } \\
\text { Prob }>\text { F }\end{array}$ \\
\hline Model & 10173.23 & 9 & 2414.62 & 10.03 & 0.0560 \\
A-power & 21327.53 & 1 & 21327.53 & 2.68 & 0.2004 \\
B-time & 8774.55 & 1 & 8774.55 & 1.10 & 0.3711 \\
C-ratio & 3621.52 & 1 & 3621.52 & 0.45 & 0.5485 \\
AB & 11146.29 & 1 & 11146.29 & 1.40 & 0.3221 \\
AC & 1816.21 & 1 & 1816.21 & 0.23 & 0.6657 \\
BC & 39958.81 & 1 & 39958.81 & 5.01 & 0.1110 \\
$\mathrm{~A}^{2}$ & 12005.48 & 1 & 4205.05 & 15.06 & 0.0303 \\
$\mathrm{~B}^{2}$ & 20909.20 & 1 & 20909.20 & 2.62 & 0.2037 \\
$\mathrm{C}^{2}$ & 55852.15 & 1 & 5852.15 & 15.01 & 0.0372 \\
Residual & 23904.85 & 3 & 7968.28 & & \\
Cor & $2.412 \mathrm{E}+005$ & 12 & & & \\
Total & & & & & \\
\hline $\mathrm{R}^{2}=0.9009$, adjusted $\mathrm{R}^{2}=0.6036$ & & & & \\
\hline & & & & & \\
\hline
\end{tabular}

It can be observed that the curvature of MW power is slightly larger than the pretreatment time, indicating that the effect of MW power on the biogas production is significantly larger than the pretreatment time. The same observation can also depict the plot of liquid-solid ratio and MW power. The curvature of MW power is slightly larger than liquid-solid ratio. In the plot of liquid-solid ratio and pretreatment time the curvature of liquidsolid ratio is less than pretreatment time, indicating that pretreatment time is a more effective factor. In contour plots, it is found that the contour line is an obvious oval, which indicates that the interaction between both the two factors are significant. This is in continuity with the variance analysis. The elliptical contour plots show the good interaction between the independent variables. The optimum conditions for the MW pretreatment are found to be, MW power at $656.92 \mathrm{~W}$, pretreatment time at $5.10 \mathrm{~min}$ and liquid-solid ratio at 33.63:1.

\subsection{Biogas Production}

MW pretreatment power of $600 \mathrm{~W}$ is used to perform the anaerobic digestion experiment to observe the real effect on biogas yield with different liquid-solid ratio and time. The biogas production influenced by different MW pretreatment conditions is shown in Fig. 4. The gas amount increased to 238, 223, 244 and $188 \mathrm{~mL}$ for the groups 20:1, $2 \mathrm{~min}$, 40:1, $4 \mathrm{~min}, 20: 1,6 \mathrm{~min}$ and control, respectively. The two groups 20:1, $6 \mathrm{~min}$ and 20:1 $2 \mathrm{~min}$ provide maximum gas production amount of $244 \mathrm{~mL}$ and $238 \mathrm{~mL}$, respectively. The group with liquid-solid ratio 40:1 and pretreatment time of 4 min showed an abrupt increase with $36 \mathrm{~mL}$ at $60 \mathrm{~h}$ as compared to control. The maximum cumulative biogas and the amount of hydrogen produced during the experiment are presented in Table 4.

The biogas production potential of carbohydrate is much higher than that of lipid and protein. The different carbohydrate content could be one of the reasons for different biogas production [18]. It can be observed form Fig. 2 (b) that the reducing sugar value increased after MW pretreatment indicating that pretreatment dissolute the Enteromorpha cell wall and releases more carbohydrate and increases biogas production.

\subsection{Change in COD and reducing sugar concentration}

The dynamic change of COD during anaerobic digestion process is shown in Fig. 5. It is found that the liquid-solid ratio in 20:1 displays good performance, especially the group of ratio $20: 1$ and $6 \mathrm{~min}$ in $600 \mathrm{~W}$ achieves highest 


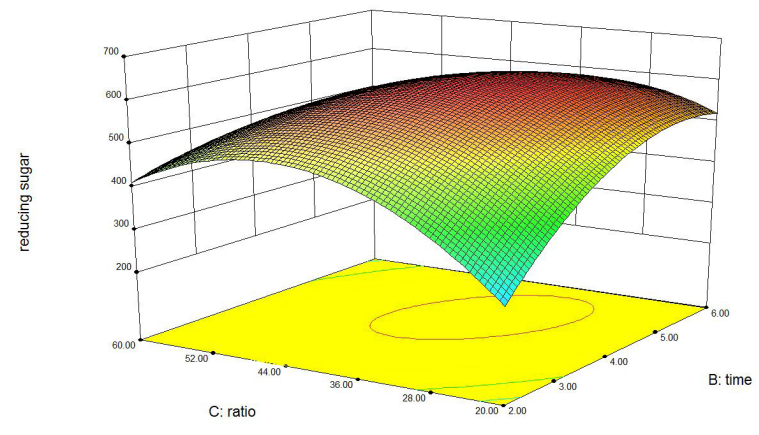

(a)

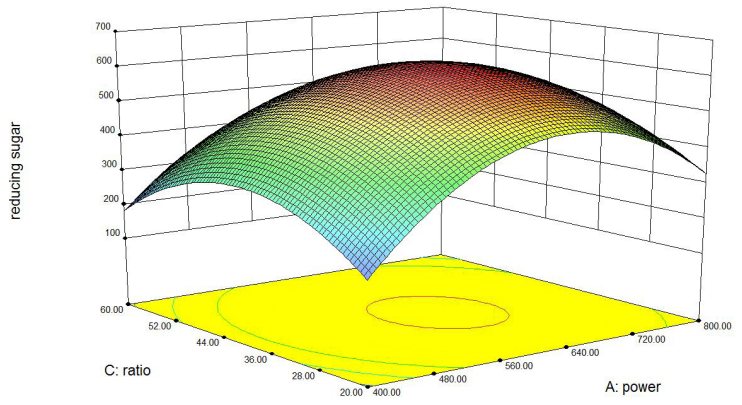

(c)

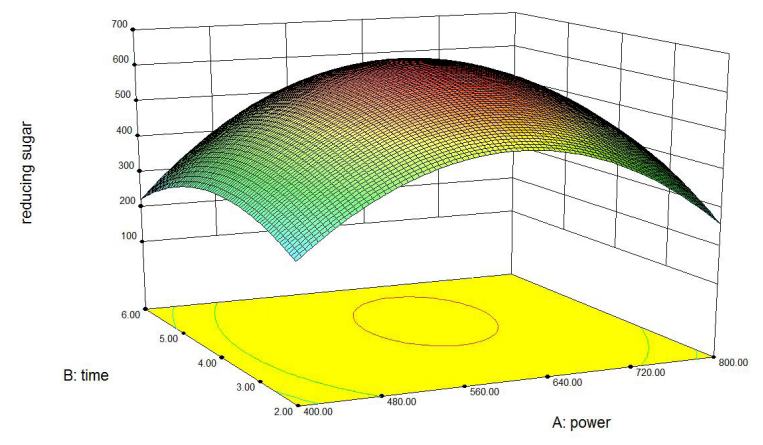

(e)

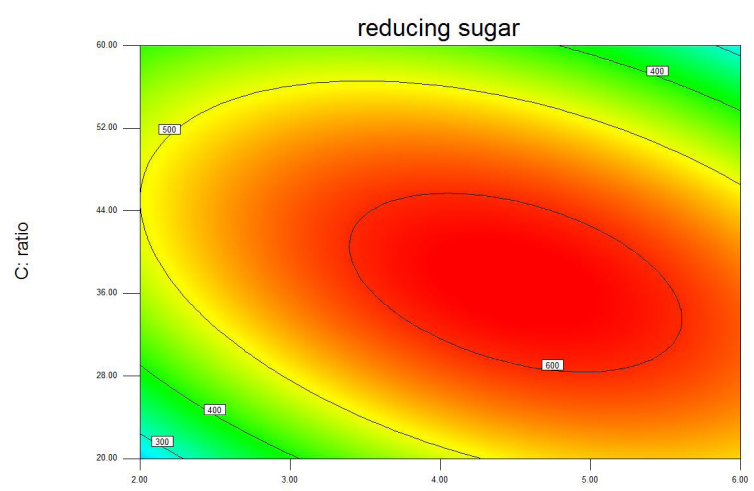

(b)

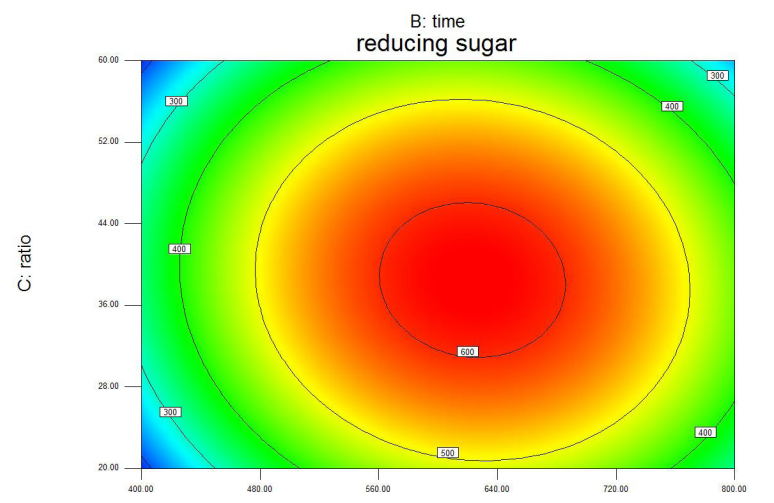

(d)

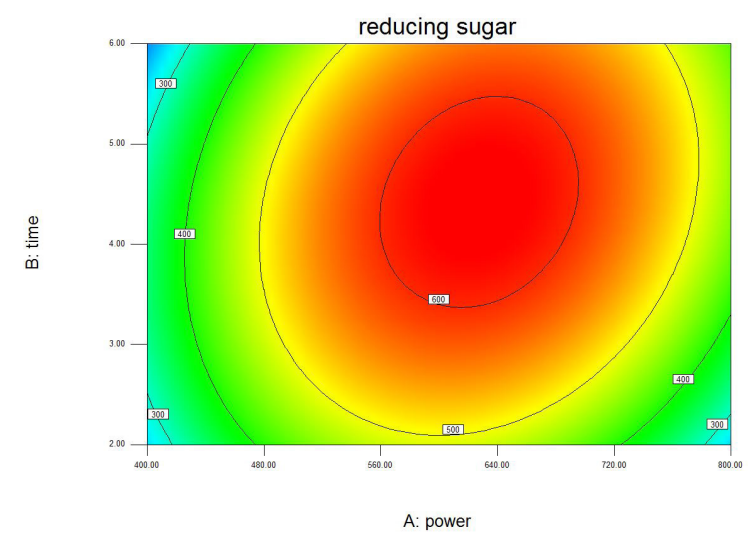

Fig. 3 (a-f) Response surface plot and Contour plots for biogas

COD value of $10,420 \mathrm{mg} / \mathrm{L}$. However, the groups of liquid-solid ratio $60: 1$ and 2 min presents a low value. Fig. 6 shows the effect for reducing sugar during anaerobic digestion. It is found that the ratio $40: 1,4$ min group provides highest value of $0.79 \mathrm{~g} / \mathrm{L}$ and provides less biogas yield. Low reducing sugar value with high gas production means that

Table 4 Cumulative biogas production and amount of hydrogen produced during the experiment

\begin{tabular}{lcccc}
\hline & Control & $\begin{array}{c}20: 1 \\
2 \mathrm{~min}\end{array}$ & $\begin{array}{c}40: 1 \\
4 \mathrm{~min}\end{array}$ & $\begin{array}{c}20: 1 \\
6 \mathrm{~min}\end{array}$ \\
\hline Cumulative Biogas (ml) & 188 & 238 & 223 & 244 \\
Hydrogen \% (v/v) & 17.53 & 49.51 & 35.64 & 45.11 \\
\hline
\end{tabular}

the most reducing sugar had been used to produce the gas in this period. The highest biogas amount with more sugar consumption during anaerobic digestion process is achieved by group 20:1, $6 \mathrm{~min}$.

\subsection{VFA production during fermentation}

The production of VFA amount measured during the experiment is shown in Fig. 7. It is found that the amount of butyric acid had a very significant change in two groups. The amount of increase can reach $2,808 \mathrm{mg} / \mathrm{L}$ and 2,644 $\mathrm{mg} / \mathrm{L}$ in group of 20:1 liquid-solid ratio, $6 \mathrm{~min}$ and 20:1 liquid-solid ratio, 2 min, respectively. High biogas yield is observed with high acetic acid and butyric 


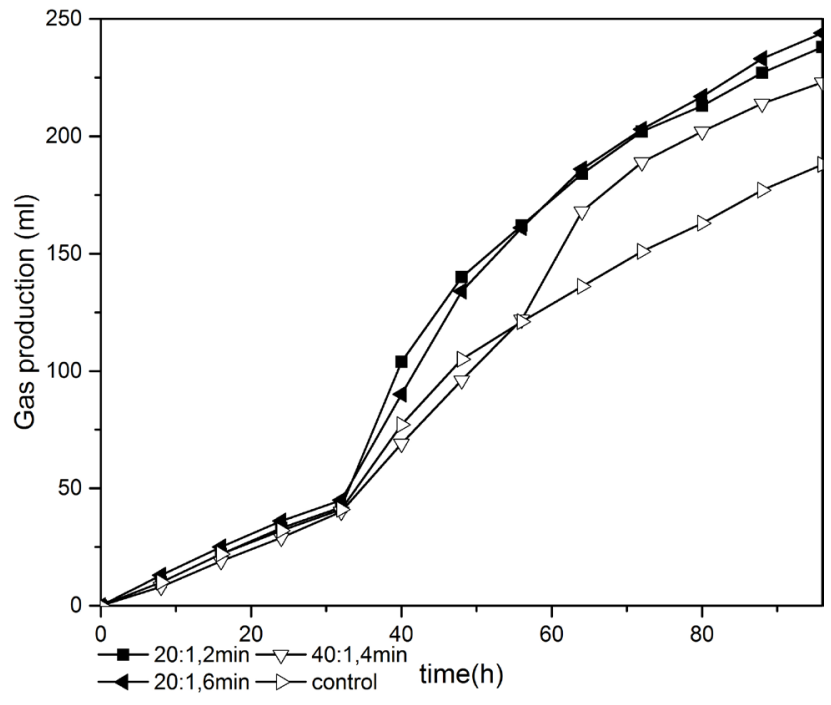

Fig. 4 Biogas production influenced by different MW pretreatment condition

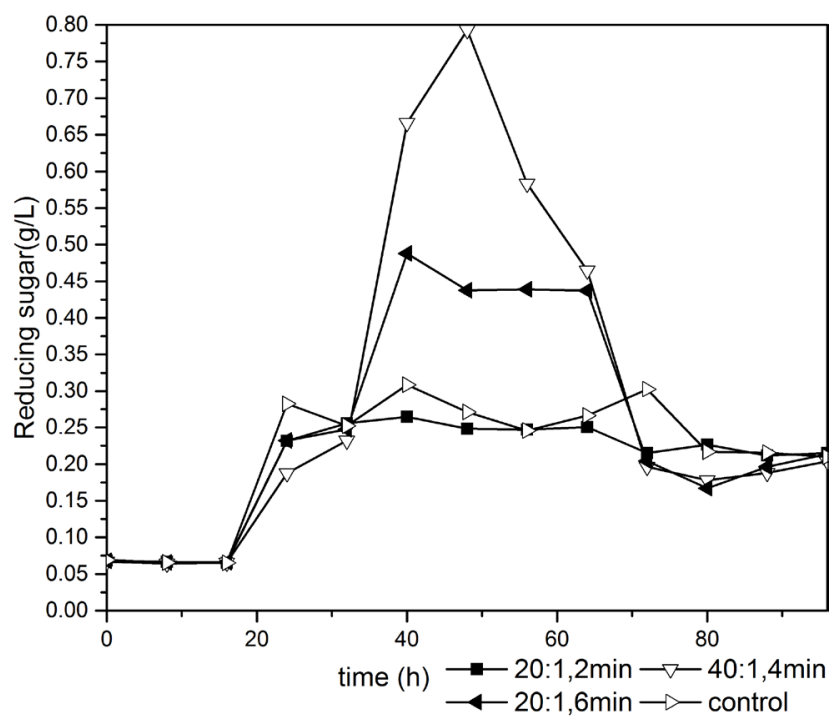

Fig. 6 Dynamic change of reducing sugar during fermentation

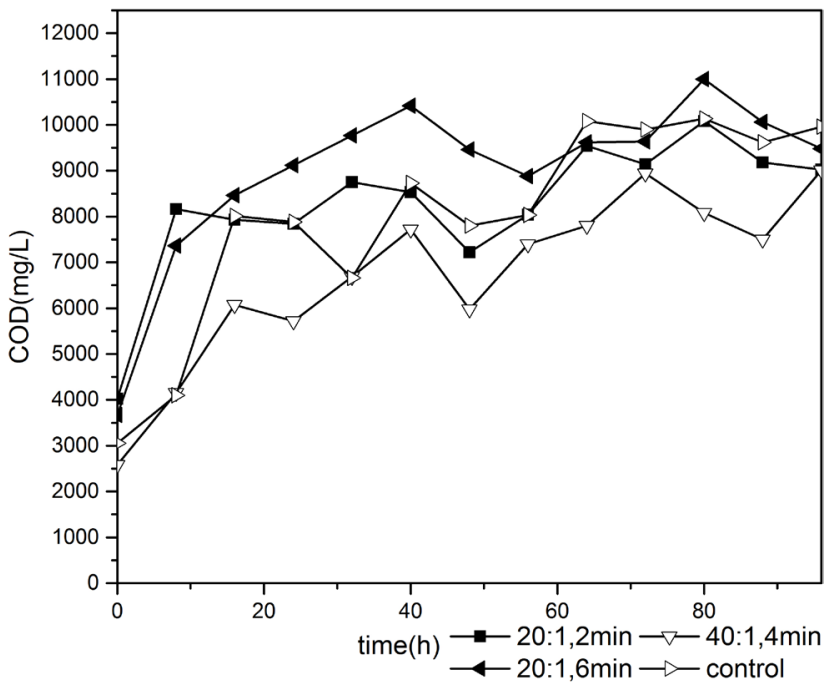

Fig. 5 Dynamic change of COD during anaerobic digestion

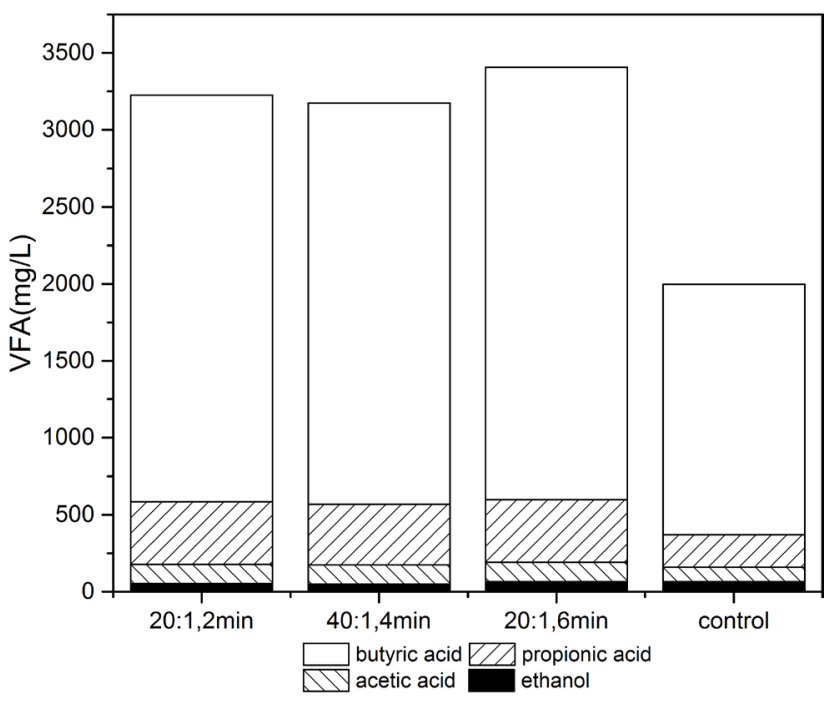

Fig. 7 VFA production affected by different MW pretreatment conditions

Table 5 Biogas potentials of pretreated microalgae

\begin{tabular}{lcccc}
\hline Pretreatment method & Algae & Pretreatment condition & Biogas yields after pretreatment & Ref. \\
\hline Beating & Pelvetia caniculata & Hollander beater & $444.3 \mathrm{~mL}$ biogas/g TS & {$[20]$} \\
Ultrasound & Hydrodictyon reticulatum & $20 \mathrm{kHz} 40 \mathrm{~J} / \mathrm{mL}$ & Methane production 2.3 times higher & {$[21]$} \\
Thermal & Scenedesmus & $80{ }^{\circ} \mathrm{C}$ & $57 \%$ methane yield increase & {$[22]$} \\
Chemical & Chlorella vulgaris & $4 \mathrm{M} \mathrm{NaOH}$ & $237.9 \mathrm{~mL} \mathrm{CH} 4 / \mathrm{g} \mathrm{COD}$ & {$[23]$} \\
& Nannochloropis salina & 5 times until boiling at $600 \mathrm{~W}$ & Biogas yield increase of $40 \%$ & {$[24]$} \\
Microwave & Micro-algal from a high rate algal ponds & $65.4 \mathrm{MJ} / \mathrm{kg} \mathrm{TS}$ & Biogas yield increase of $78 \%$ & {$[25]$} \\
& Enteromorpha & Shown above & $24.4 \mathrm{~mL}$ biogas/g dry algae & This \\
& & & & study \\
\hline
\end{tabular}


acid production. In contrast, it had a low level ethanol amount, and it is found that ethanol accumulation negatively affects the biogas yield, since ethanol production has no contribution to biogas production [19]. The Table 5 listed the biogas potentials between different pretreatment of microalgae.

\section{Conclusions}

The MW pretreatment enhanced the biogas production by providing highest amount of biogas yield with $244 \mathrm{~mL}$, amount of COD with $10,420 \mathrm{mg} / \mathrm{L}$ and a highest amount of increase of reducing sugar from $0.24 \mathrm{~g} / \mathrm{L}$ to $0.79 \mathrm{~g} / \mathrm{L}$. The best conditions of Enteromorpha MW pretreatment are: MW

\section{References}

[1] Saleh, N., Mushtaq, K., Zaidi, A. A., Abbasoglu, S., Faiz Ahmed, S. "Design and Performance Analysis of a Solar Powered Hybrid Rickshaw for Commercial Use in Pakistan", Journal of Environmental Science and Technology, 9(6), pp. 472-480, 2016. https://doi.org/10.3923/jest.2016.472.480

[2] Zhang, Q., Hu, J., Lee, D.-J. "Biogas from anaerobic digestion processes: Research updates", Renewable Energy, 98, pp. 108-119, 2016.

https://doi.org/10.1016/j.renene.2016.02.029

[3] Mushtaq, K., Zaidi, A. A., Askari, S. J. "Design and performance analysis of floating dome type portable biogas plant for domestic use in Pakistan", Sustainable Energy Technologies and Assessments, 14, pp. 21-25, 2016. https://oi.org/10.1016/j.seta.2016.01.001

[4] Al Seadi, T., Rutz, D., Prassl, H., Köttner, M., Finsterwalder, T., Volk, S., Janssen, R. "Biogas Handbook", University of Southern Denmark Esbjerg, Esbjerg, Denmark, 2008.

[5] Hagos, K., Zong, J., Li, D., Liu, C., Lu, X. "Anaerobic co-digestion process for biogas production: Progress, challenges and perspectives", Renewable and Sustainable Energy Reviews, 76, pp. 1485-1496, 2017.

https://doi.org/10.1016/j.rser.2016.11.184

[6] Mao, C., Feng, Y., Wang, X., Ren, G. "Review on research achievements of biogas from anaerobic digestion", Renewable and Sustainable Energy Reviews, 45, pp. 540-555, 2015. https://doi.org/10.1016/j.rser.2015.02.032

[7] Yin, D., Liu, W., Zhai, N., Yang, G., Wang, X., Feng, Y., Ren, G. "Anaerobic digestion of pig and dairy manure under photo-dark fermentation condition", Bioresource Technology, 166, pp. 373380, 2014.

https://doi.org/10.1016/j.biortech.2014.05.037

[8] Xia, A., Cheng, J., Song, W., Su, H., Ding, L., Lin, R., Lu, H., Liu, J., Zhou, J., Cen, K. "Fermentative hydrogen production using algal biomass as feedstock", Renewable and Sustainable Energy Reviews, 51, pp. 209-230, 2015.

https://doi.org/10.1016/j.rser.2015.05.076 power $656.92 \mathrm{~W}$, pretreatment time $5.10 \mathrm{~min}$, liquid-solid ratio 33.63:1. The presented results demonstrate the practicability of RSM optimum strategy and show the robustness of MW pretreatment with anaerobic digestion of microalgae (Enteromorpha) for enhancement in biogas yield.

\section{Acknowledgement}

This research was financially supported by the National Key R\&D Plan of China (2017YFC1404605), the Natural Science Foundation of China (Grant No. 51579049 and 51509044), the Fundamental Research Funds for the Central Universities (HEUCFG201820) and the High Tech Ship Program.

[9] Ren, H.-Y., Liu, B.-F., Kong, F., Zhao, L., Ren, N. "Hydrogen and lipid production from starch wastewater by co-culture of anaerobic sludge and oleaginous microalgae with simultaneous COD, nitrogen and phosphorus removal", Water Research, 85, pp. 404412, 2015.

https://doi.org/10.1016/j.watres.2015.08.057

[10] Wang, J., Yin, Y. "Fermentative hydrogen production using pretreated microalgal biomass as feedstock", Microbial Cell Factories, 17(22), pp. 1-16, 2018.

https://doi.org/10.1186/s12934-018-0871-5

[11] Deepanraj, B., Sivasubramanian, V., Jayaraj, S. "Effect of substrate pretreatment on biogas production through anaerobic digestion of food waste", International Journal of Hydrogen Energy, 42(42), pp. 26522-26528, 2017. https://doi.org/10.1016/j.ijhydene.2017.06.178

[12] Box, G. E. P., Wilson, K. B. "On the Experimental Attainment of Optimum Conditions", In: Kotz, S., Johnson, N. L. (eds.) Breakthroughs in Statistics, Springer Series in Statistics (Perspectives in Statistics), Springer, New York, USA, 1992, pp. 270-310.

https://doi.org/10.1007/978-1-4612-4380-9_23

[13] Waligórska, M. "Fermentative Hydrogen Production - Process Design and Bioreactors", Chemical and Process Engineering, 33(4), pp. 585-594, 2012.

https://doi.org/10.2478/v10176-012-0048-4

[14] Ren, N.-Q., Zhao, L., Chen, C., Guo, W.-Q., Cao, G.-L. "A review on bioconversion of lignocellulosic biomass to $\mathrm{H}_{2}$ : Key challenges and new insights", Bioresource Technology, 215, pp. 92-99, 2016. https://doi.org/10.1016/j.biortech.2016.03.124

[15] Xia, A., Jacob, A., Tabassum, M. R., Herrmann, C., Murphy, J. D. "Production of hydrogen, ethanol and volatile fatty acids through co-fermentation of macro- and micro-algae", Bioresource Technology, 205, pp. 118-125, 2016. https://doi.org/10.1016/j.biortech.2016.01.025

[16] Karadag, D., Puhakka, J. A. "Effect of changing temperature on anaerobic hydrogen production and microbial community composition in an open-mixed culture bioreactor", International Journal of Hydrogen Energy, 35(20), pp. 10954-10959, 2010. https://doi.org/10.1016/j.ijhydene.2010.07.070 
[17] Chinese Environmental Protection Chief Bureau, Water and Wastewater Monitoring and Analysis Association "Standard Methods for the Examination of Water and Waste Water", 4th ed., Chinese Environmental Sciences Press, Beijing, China, 2002.

[18] Dong, L., Zhenhong, Y., Yongming, S., Xiaoying, K., Yu, Z. "Hydrogen production characteristics of the organic fraction of municipal solid wastes by anaerobic mixed culture fermentation", International Journal of Hydrogen Energy, 34(2), pp. 812 820,2009 https://doi.org/10.1016/j.ijhydene.2008.11.031

[19] Jiang, D., Ge, X., Zhang, T., Liu, H., Zhang, Q. "Photo-fermentative hydrogen production from enzymatic hydrolysate of corn stalk pith with a photosynthetic consortium", International Journal of Hydrogen Energy, 41(38), pp. 16778-16785, 2016. https://doi.org/10.1016/j.ijhydene.2016.07.129

[20] Tedesco, S., Benyounis, K. Y., Olabi, A. G. "Mechanical pretreatment effects on macroalgae-derived biogas production in co-digestion with sludge in Ireland", Energy, 61, pp. 27-33, 2013. https://doi.org/10.1016/j.energy.2013.01.071

[21] Lee, K., Chantrasakdakul, P., Kim, D., Kong, M., Park, K. Y. "Ultrasound pretreatment of filamentous algal biomass for enhanced biogas production, Waste Management, 34(6), pp. 10351040, 2014.

https://doi.org/10.1016/j.wasman.2013.10.012
[22] González-Fernández, C., Sialve, B., Bernet, N., Steyer, J. P. "Thermal pretreatment to improve methane production of Scenedesmus biomass", Biomass and Bioenergy, 40, pp. 105-111, 2012. https://doi.org/10.1016/j.biombioe.2012.02.008

[23] Mendez, L., Mahdy, A., Timmers, R. A., Ballesteros, M., GonzálezFernández, C. "Enhancing methane production of Chlorella vulgaris via thermochemical pretreatments", Bioresource Technology, 149, pp. 136-141, 2013.

https://doi.org/10.1016/j.biortech.2013.08.136

[24] Schwede, S., Kowalczyk, A., Gerber, M., Span, R. "Influence of Different Cell Disruption Techniques on Mono Digestion of Algal Biomass", In: World Renewable Energy Congress, Linköping, Sweden, 2011, pp. 41-47. https://doi.org/10.3384/ecp1105741

[25] Passos, F., Solé, M., García, J., Ferrer, I. "Biogas production from microalgae grown in wastewater: Effect of microwave pretreatment", Applied Energy, 108, pp. 168-175, 2013. https://doi.org/10.1016/j.apenergy.2013.02.042 